\title{
STUDIES ON SERUM PROTEINS. I. IDENTIFICATION OF A SIN- GLE SERUM GLOBULIN BY IMMUNOLOGICAL MEANS. ITS DISTRIBUTION IN THE SERA OF NORMAL INDIVIDUALS AND OF PATIENTS WITH CIRRHOSIS OF THE LIVER AND WITH CHRONIC GLOMERULONEPHRITIS ${ }^{1}$
}

\author{
By FORREST E. KENDALL \\ (From the Research Division of Chronic Diseases, Department of Hospitals, City of New York, \\ and the Department of Medicine, College of Physicians and Surgeons, Columbia \\ University, New York City)
}

(Received for publication July 14,1937 )

It has long been known that the globulin fraction of normal human serum contains more than one variety of protein. The separation of this fraction into euglobulin and pseudoglobulin and the further fractionation of pseudoglobulin into pseudoglobulin I and pseudoglobulin II (1) upon the basis of solubility in strong salt solutions confirms this. However, such fractions are still mixtures and can be further divided into subfractions having different chemical and physical properties by dialysis (2) or by partial precipitation with salts (3).

The existence in the globulin fraction of serum of at least two proteins which are antigenically different has been demonstrated by anaphylaxis. Animals sensitized by the injection of the euglobulin or pseudoglobulin fractions are thrown into anaphylactic shock more easily by subsequent injections of the homologous rather than the heterologous fraction (4). Animals immunized with either of the two globulin fractions produce precipitins that react with both fractions. However, quantitative differences in the reactions indicate the presence of two antigens in different proportions in the two fractions and of two corresponding kinds of antibody in the antisera (5).

These observations suggested that if part of the antibody contained in an antiglobulin serum could be absorbed out leaving antibodies to but one of the globulins, such a serum would be a useful guide for the isolation and identification of that globulin. The development of the precipitin reaction as a quantitative method for the estimation of an antigen (6) or hapten (7) makes it possible to use such antisera for the determination of

\footnotetext{
1 This work was supported in part by a grant from the Edward Daniels Faulkner Arthritis Clinic.
}

the actual amount of the varieties of globulin present in human serum or in any of the fractions derived from it.

\section{Preparation of globulin fractions}

Two hundred and ten $\mathrm{ml}$. of human serum, from a patient with hypertension, was separated into euglobulin, pseudoglobulin, and albumin fractions by precipitation at one-third and one-half saturation with ammonium sulfate. The euglobulin fraction was reprecipitated five times by the slow addition of $25 \mathrm{ml}$. of saturated ammonium sulfate solution to the protein dissolved in $50 \mathrm{ml}$. of water. The pseudoglobulin was also reprecipitated five times by the addition of $50 \mathrm{ml}$. of the ammonium sulfate solution to $50 \mathrm{ml}$. of protein solution.

The euglobulin and pseudoglobulin fractions were freed from sulfate by dialysis against 0.9 per cent sodium chloride solution. Part of the solutions were then fractionated into water soluble and water insoluble fractions by dialysis, first against running tap water and then against distilled water in the ice box.

The water insoluble fractions were dissolved in 0.9 per cent saline. One per cent by volume of a 1 per cent solution of merthiolate ${ }^{2}$ was added to each of the fractions, and they were sterilized by filtration through L2 Chamberland filters. Each solution was analyzed by the micro-Kjeldahl technic for total nitrogen and for nonprotein nitrogen.

Five more samples of human serum, four from different patients with hypertension, and one, L2, a mixture of sera from five normal persons were separated into the water soluble and water in-

\footnotetext{
2 Manufactured by Eli Lilly \& Co., Indianapolis, Ind.
} 
soluble euglobulin and pseudoglobulin fractions by the method described above.

\section{Preparation of antisera}

Alum-precipitated suspensions (8) were prepared by adding $5 \mathrm{ml}$. of a sterile, 5 per cent solution of crystalline potassium aluminium sulfate to a solution containing $100 \mathrm{mgm}$. of globulin and then adding $0.4 \mathrm{ml}$. of 10 per cent $\mathrm{NaOH}$, a quantity sufficient to neutralize the alum solution used. The suspension was diluted to $100 \mathrm{ml}$. with sterile saline. Rabbits received a course of four intravenous injections a week of this suspension, beginning with $1 / 2 \mathrm{ml}$. injections the first week, 1 $\mathrm{ml}$. the second and $2 \mathrm{ml}$. thereafter. After the fourth week, bleedings of from 40 to $50 \mathrm{ml}$. were made from either the heart or the ear artery, without sacrificing the animal, and after a rest for a week the course of injections was continued. Additional bleedings were then made at intervals of from three to four weeks. After separation of the sera, one per cent by volume of a one per cent solution of merthiolate was added as a preservative, and the sera were sterilized by filtration and stored in the ice box.

\section{Reaction of the globulin fractions with rabbit antiglobulin serum Number 389}

A preliminary experiment was made with antiglobulin serum Number 389, prepared by immunizing a rabbit with the water insoluble euglobulin fraction of normal human serum.

Solutions in 0.9 per cent saline of each of the globulin fractions containing about $0.04 \mathrm{mgm}$. of globulin nitrogen per $\mathrm{ml}$. were prepared. One, two and three $\mathrm{ml}$. samples of each were measured out into $8 \mathrm{ml}$. Wassermann tubes, the total volume made up to $3 \mathrm{ml}$. in each case with saline and $1 \mathrm{ml}$. of antiserum added. After thorough mixing of the contents, the tubes were sealed with " no-air" rubber stoppers, allowed to stand for two hours in an incubator at $37^{\circ} \mathrm{C}$., and placed in the ice box overnight. The following morning the tubes were centrifuged for 30 minutes at 2000 r.p.m. in a refrigerated centrifuge at 2 to $4^{\circ} \mathrm{C}$. The clear supernatant fluids were carefully poured off and saved for testing. The compact precipitates were resuspended in $1.5 \mathrm{ml}$. of ice cold saline and recentrifuged. The supernatant saline solutions were discarded and the precipitates were again washed with $1.5 \mathrm{ml}$. of saline. Finally, the precipitates were suspended in saline, dissolved by the addition of a few drops of $\mathrm{N}$ sodium hydroxide, transferred to $100 \mathrm{ml}$. micro-Kjeldahl flasks, and analyzed for nitrogen by the micro-Kjeldahl method.

The results of the analysis are shown in graphic form in Figure 1, where the nitrogen found in the precipitate is plotted against the globulin nitrogen added. Smooth curves of the type shown by Heidelberger and Kendall (6) to be characteristic of the precipitin reaction are drawn through the points for the whole euglobulin fraction and for the two pseudoglobulin fractions. The values found for the two euglobulin subfractions are indicated by circles. A given quantity of the whole euglobulin precipitated more nitrogen from the antiserum than did the same amount of any of the other fractions. Or, expressed in a different way, it required less of the whole euglobulin than of the other fractions to precipitate a given amount of nitrogen. It will be seen from the figure that while it required only $0.042 \mathrm{mgm}$. of nitrogen in the whole euglobulin to precipitate $0.40 \mathrm{mgm}$. of nitrogen from the antiserum, it required 0.066 mgm. of the water insoluble pseudoglobulin nitrogen and $0.120 \mathrm{mgm}$. of water soluble pseudoglobulin nitrogen to precipitate the same amount. This would indicate that these two fractions contained but 65 per cent and 35 per cent as much protein that reacted with the antiserum as did the whole euglobulin fraction. In spite of the fact that the water insoluble euglobulin fraction was used as antigen in the production of the antiserum the figure-shows that it was only about 70 per cent as efficient as the whole euglobulin in reacting with the antiserum. These figures do not represent the quantity of any definite antigen in the fractions but refer to the rather vague expression " protein that reacts with the antiserum." The tests upon the supernatant fluids show that more than one kind of antibody is present in this antiserum. In order to use the antiserum for the determination of any particular antigen all of the antibody for other antigens must be removed.

\section{Tests upon the supernatant fluids}

Five-tenths $\mathrm{ml}$. portions of the supernatant fluids from the experiment described above were added to $0.1 \mathrm{ml}$. samples of (a) the antiserum 


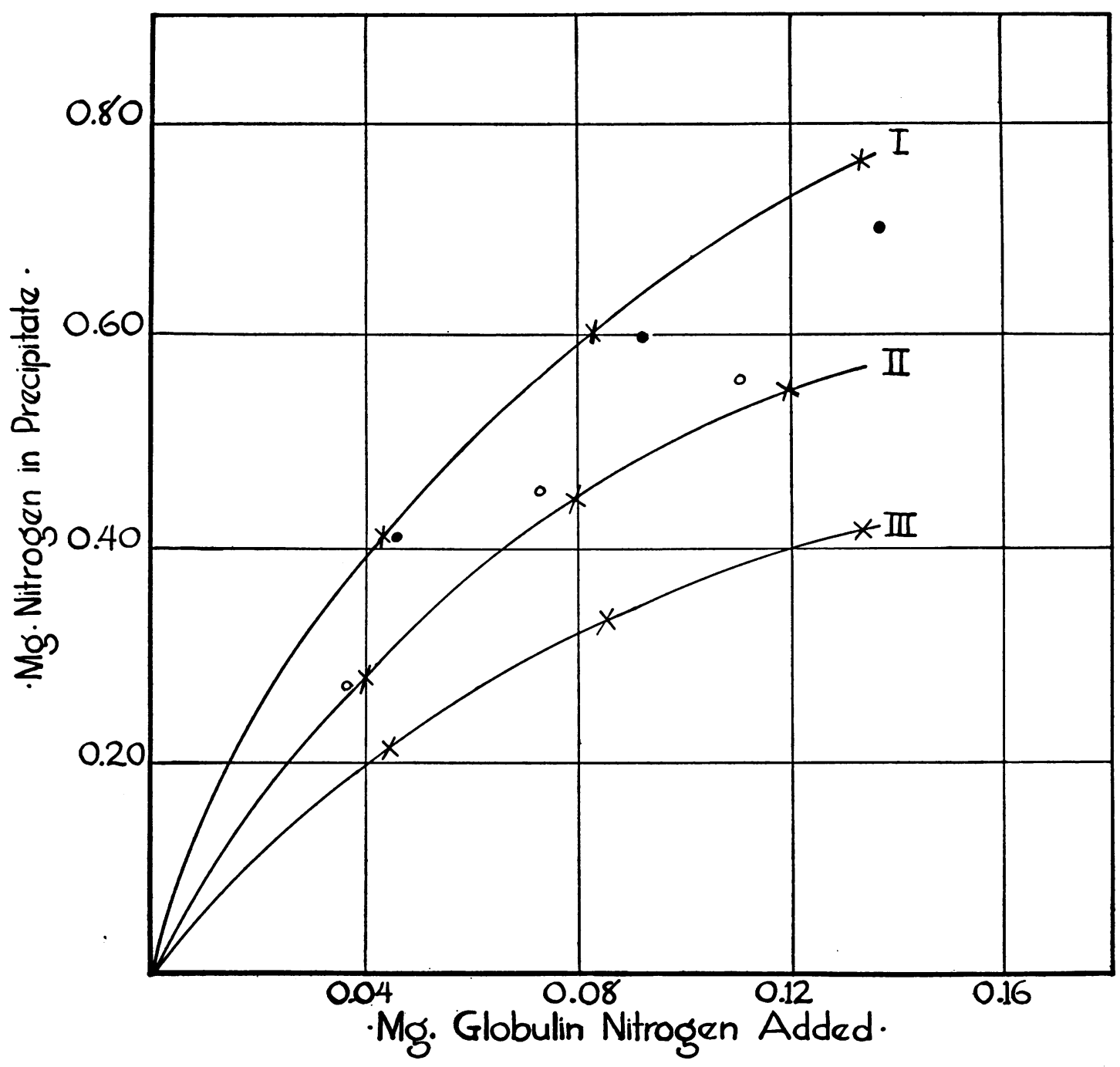

Fig. 1. Nitrogen Precipitated from Anti-euglobulin Rabbit Serum Number 389 by Globulin FRACTIONS

I Whole euglobulin.

II Water insoluble pseudoglobulin. III Water soluble pseudoglobulin.
Water soluble euglobulin.

$\odot$ Water insoluble euglobulin. and $(b)$ the saline solutions of the different globulin fractions. These mixtures were kept at $37^{\circ} \mathrm{C}$. for 2 hours, overnight in the ice box, and were then examined for the presence of a precipitate. The results of these tests are presented in Table I. This experiment demonstrates (a) that the antiserum contained more than one type of antibody and $(b)$ that with the exception of the water soluble euglobulin fraction, the globulin fractions were mixtures containing more than one type of antigen.
Comparison of the precipitin reaction with a more familiar type of chemical reaction may make the significance of the tests upon the supernatant fluids more apparent. In many of its aspects, the reaction between a protein and its corresponding antibody to form a precipitate is not unlike the more familiar chemical reactions which result in the formation of precipitates. If a solution of silver ions is mixed with one containing chloride ions, silver chloride will be precipitated, and the supernatant fluid will contain only the component 
TABLE I

Nitrogen precipitated from rabbit antiserum Number 389 by globulin fractions

\begin{tabular}{|c|c|c|c|c|c|c|c|c|}
\hline \multirow{3}{*}{ Fraction } & \multirow{3}{*}{$\begin{array}{c}\text { Glob- } \\
\text { ulin } \\
\text { nitro- } \\
\text { gen } \\
\text { added }\end{array}$} & \multirow{3}{*}{$\begin{array}{c}\text { Nitro- } \\
\text { gen } \\
\text { in } \\
\text { pre- } \\
\text { cipi- } \\
\text { tate }\end{array}$} & \multicolumn{6}{|c|}{ Tests upon supernatant fuids } \\
\hline & & & \multicolumn{6}{|c|}{ Added } \\
\hline & & & Anti- & $\begin{array}{c}\text { Eu- } \\
\text { glob- } \\
\text { ulin }\end{array}$ & $\begin{array}{c}\text { Eu- } \\
\text { glob- } \\
\text { ulin } \\
\text { sol- } \\
\text { uble }\end{array}$ & $\begin{array}{c}\text { Eu- } \\
\text { glob- } \\
\text { ulin } \\
\text { insol- } \\
\text { uble }\end{array}$ & $\begin{array}{l}\text { Pseudo- } \\
\text { soluble }\end{array}$ & $\begin{array}{l}\text { Pseudo- } \\
\text { insoluble }\end{array}$ \\
\hline Euglobulin & \begin{tabular}{|l} 
mgm. \\
0.044 \\
0.088 \\
0.132
\end{tabular} & $\begin{array}{l}\text { mom. } \\
0.410 \\
0.598 \\
0.710\end{array}$ & $\bar{t}$ & & & & $\stackrel{++}{ \pm}$ & $\stackrel{++}{ \pm}$ \\
\hline $\begin{array}{l}\text { Euglobulin } \\
\text { H.t20 soluble }\end{array}$ & $\begin{array}{l}0.046 \\
0.092 \\
0.137\end{array}$ & $\begin{array}{l}0.410 \\
0.596 \\
0.658\end{array} \mid$ & $\bar{t}$ & & $\stackrel{+ \pm \pm}{=}$ & $\begin{array}{c}++ \pm \\
+ \pm \\
+\end{array}$ & & \\
\hline $\begin{array}{l}\text { Euglobulin } \\
\mathrm{H}_{2} \mathrm{O} \text { insolu- } \\
\text { ble }\end{array}$ & $\begin{array}{l}0.037 \\
0.073 \\
0.110\end{array}$ & $\begin{array}{l}0.270 \\
0.454 \\
0.562\end{array} \mid$ & $\dot{t}$ & & $\begin{array}{l}+++ \\
++ \\
++\end{array}$ & $\begin{array}{l}+++ \\
++ \\
++\end{array}$ & & \\
\hline $\begin{array}{l}\text { Pesudoglobulin } \\
\text { Ho } 0 \text { soluble }\end{array}$ & $\begin{array}{l}0.044 \\
0.088 \\
0.132\end{array}$ & \begin{tabular}{l|}
0.216 \\
0.324 \\
0.418
\end{tabular} & $\stackrel{+}{+}$ & $\begin{array}{l}+++ \\
+++ \\
+++\end{array}$ & & & $\begin{array}{l}++ \\
+ \\
+\end{array}$ & $\begin{array}{l}++t \\
++t \\
++t\end{array}$ \\
\hline $\begin{array}{l}\text { Pseudoglobulin } \\
\mathrm{H}_{3} \mathrm{O} \text { insolu- } \\
\text { ble }\end{array}$ & $\begin{array}{l}0.040 \\
0.080 \\
0.120\end{array}$ & $\begin{array}{l}0.282 \\
0.452 \\
0.556\end{array}$ & $\stackrel{+}{+}$ & $\begin{array}{l}+++ \\
++ \pm \\
++\end{array}$ & & & $\begin{array}{c}++ \\
+ \\
+\end{array}$ & ++ \\
\hline
\end{tabular}

which had been added in excess. The addition of more silver ions will give a precipitate only if an excess of chloride ions is present, and additional chloride ions will cause precipitation only when there is an excess of silver ions. Both tests will not be positive at the same time. However, if the solutions, instead of containing a single pair of reacting ions, are mixtures containing more than one system, different results may be obtained. Thus, if a solution containing a mixture of silver and barium ions is added to the one containing both chloride and sulfate ions, the supernatant fluid may give a precipitate when tested with either of the two solutions. If the first solution contained 2 equivalents of silver and 3 of barium and the second one 3 equivalents of chloride and 2 of sulfate, the supernatant fluid would contain 1 equivalent each of barium and of chloride and would give a heavy precipitate when added to either the silver-barium or the chloride-sulfate solutions. This behavior in an inorganic system is evidence that it contains more than one pair of reacting ions.

The reaction between antigen and antibody behaves in a similar manner: the formation of a precipitate upon the addition of antiserum indicates the presence of an excess of antigen, whereas a precipitate following the addition of antigen shows the presence of an excess of antibody. Positive tests for both antigen and antibody are not given by the same supernatant fluid in a system containing a single antigen and its homologous antibody. Positive tests for both constitute definite evidence that the antiserum contains more than one kind of antibody and that the antigen is a mixture of antigenic components.

The results given in Table I definitely show that the antiserum contained more than one type of antibody and that all but one of the globulin fractions were mixtures of antigens. In many cases, precipitates were obtained when the supernatant fluids were tested with either more antiserum or more of the globulin fractions.

The tests upon the supernatant fluids of the series to which the water soluble euglobulin had been added showed an important difference between this fraction and the others. In this series, if the test for excess antibody was positive, the test for antigen was negative. If the test for excess antigen was positive, the test for antibody was negative. Since the antiserum is known to contain more than one kind of antibody this observation must result from one of two conditions. Either this fraction contains but one antigenic globulin or the different globulins were present in such proportions that all of the different kinds of antibody were removed simultaneously. The second possibility was ruled out by tests with fractions known to be mixtures which showed that those supernatant fluids which failed to react with the water soluble euglobulin still contained an abundance of antibody that would react with the other fractions. The water soluble euglobulin reacts with antiserum as if it were a single antigen.

The antigen contained in the water soluble euglobulin fraction will be referred to, throughout this paper, as alpha-globulin. The remainder of the globulin, which may contain more than one antigenic component, will be called globulin- $X$.

The tests upon the supernatant fluids from the series to which the whole euglobulin had been added showed that this fraction contained both alpha-globulin and globulin- $X$. The supernatant fluid from the last tube did not react with any of the globulin fractions. All of the antibody for both the alpha-globulin and the globulin- $X$ had been removed. The difference between the maximum amount of nitrogen precipitated by this frac- 
tion and by the water soluble euglobulin which contained only alpha-globulin is a measure of the quantity of nitrogen precipitated by globulin- $X$. Figure 1 shows that this amounts to $0.07 \mathrm{mgm}$. or about 10 per cent of the total quantity. The tests upon the first tube of the whole euglobulin series show that the amount of euglobulin added did not contain enough globulin- $X$ both to completely precipitate this small amount of antibody and to leave an excess to react with the test antiserum. The percentage of globulin- $X$ in this fraction must be small.

The tests upon the water insoluble euglobulin and the two pseudoglobulin fractions show that even in the first tubes enough globulin- $X$ had been added to leave an excess that reacted with the corresponding antibodies in the test portion of antiserum added. The tests upon the last tubes of the series show that the amount of alphaglobulin added was insufficient to precipitate all of its antibody. The percentage of alpha-globulin in these fractions must be lower than in the whole euglobulin fraction.

Since the antiserum contains a high percentage of antibody that reacts with alpha-globulin and only a small amount of antibody that reacts with globulin- $X$, the percentages of "protein reacting with the antiserum " found in the first part of this experiment are approximations of the alphaglobulin content of the fractions.

This experiment shows that the water soluble euglobulin fraction reacts like a pure antigen with antiserum. It shows that the other fractions are mixtures containing more than one antigen and that the antiserum used contained more than one kind of antibody.

\section{Reaction of alpha-globulin with antiglobulin serum Number 78}

The preceding experiment showed that the water soluble euglobulin fraction reacted with an anti-euglobulin rabbit serum as if it contained a single antigen. In this experiment, the reaction of this fraction is studied with an antiserum prepared by immunizing rabbits with the unfractionated globulin of normal human serum. One ml. of rabbit serum Number 78 was mixed with various amounts of alpha-globulin (water soluble euglobulin), and the amount of nitrogen in the resulting precipitate was determined following the procedure described in the first experiment. The supernatant fluids were tested for the presence of excess antigen and antibody as before. The results are given in Table II. It will be seen from

TABLE II

Reaction of the water soluble euglobulin with antiglobulin serum Number 78

\begin{tabular}{|c|c|c|c|c|c|}
\hline \multirow{3}{*}{$\begin{array}{l}\text { Euglobulin } \\
\text { nitrogen } \\
\text { added }\end{array}$} & \multicolumn{2}{|c|}{ Nitrogen precipitated } & \multicolumn{3}{|c|}{ Tests upon supernatant fluids } \\
\hline & \multirow[b]{2}{*}{ Found } & \multirow[b]{2}{*}{ Calculated } & \multicolumn{3}{|c|}{ Added } \\
\hline & & & $\begin{array}{l}\text { Anti- } \\
\text { serum }\end{array}$ & $\begin{array}{c}\mathrm{H}_{2} \mathrm{O} \\
\text { soluble } \\
\text { euglobu- } \\
\substack{\text { lin }}\end{array}$ & $\begin{array}{c}\mathrm{H}_{8} \mathrm{O} \\
\text { soluble } \\
\text { pseudo- } \\
\text { globulin }\end{array}$ \\
\hline $\begin{array}{l}\text { mgm. } \\
0.023 \\
0.046 \\
0.069 \\
0.092 \\
0.115 \\
0.137\end{array}$ & $\begin{array}{c}\text { mgm. } \\
0.178 \\
0.324 \\
0.464 \\
0.552 \\
0.638 \\
0.734\end{array}$ & $\begin{array}{l}\text { mgm. } \\
0.178 \\
0.331 \\
0.459 \\
0.561 \\
0.637\end{array}$ & $\begin{array}{l}- \\
- \\
- \\
-\end{array}$ & \pm & \\
\hline
\end{tabular}

the table that no evidence was found that the alpha-globulin contained more than one antigen. Although the difference between the successive amounts of alpha-globulin added was made small to permit the detection of small amounts of globulin- $X$, no evidence was found for the presence of that protein in this fraction. The tests upon the supernatant fluids show that no antigen was left behind to react with added antiserum at any point in the range studied. In the last tube, in which all of the antibody reacting with alpha-globulin had been removed, there still remained antibody reacting with the globulin- $X$ contained in the pseudoglobulin fractions. If a second protein is contained in the alpha-globulin, it is not a precipitinogen, that is, it does not react with antiserum to give a precipitate.

Heidelberger and Kendall (6) have shown that the reaction between a pure antigen and its homologous antibody follows the equation:

$$
M g m \text {. nitrogen precipitated }=A X-B X^{2} \text {, }
$$

where $A$ and $B$ are constants having definite physical significance (see (6)) and $X$ represents the amount of antigen nitrogen added. For serum Number 78, this equation is :

$$
\text { Mgm. nitrogen precipitated }=8.3 X-24 X^{2} \text {. }
$$

The values calculated from this equation are given in Table II where they may be compared with the 
corresponding experimental values. The close agreement of the figures is additional evidence that the water soluble euglobulin contains but a single antigen.

This experiment shows that in its reaction with antiglobulin rabbit serum, the water soluble euglobulin reacts both qualitatively and quantitatively as if it contained a single antigenic component.

\section{Absorption of antibodies for globulin- $X$ from antiglobulin rabbit serum}

Thirty ml. of antiserum from each of two rabbits, which had been immunized with the whole globulin fraction of normal human serum, were treated with small portions of the water soluble pseudoglobulin fraction, rich in globulin- $X$ until tests with unabsorbed antiserum showed the presence of an excess of globulin- $X$. A test portion of the antiserum was treated with an excess of alpha-globulin. After centrifuging down the precipitate, the supernatant fluid was tested for the presence of antibody reacting with globulin- $X$ by the addition of a dilute solution of one of the pseudoglobulin fractions. A negative test at this point showed that all of the antibody reacting with globulin- $X$ had been removed. The serum was filtered through an L2 Chamberland filter and after the addition of $1 \mathrm{ml}$. of a 1 per cent solution of merthiolate stored in the ice box.

It was found to be more difficult to remove the antibodies for globulin- $X$ from antisera obtained by long immunization or from bleedings made after continuing the immunization after the first bleeding. Thus a second bleeding from the two rabbits, described above, still contained antibodies that reacted with globulin- $X$ after treatment with the water-soluble pseudoglobulin fraction, as described above. Although the treated sera contained an excess of globulin- $X$, as shown by its reaction with unabsorbed antisera, it still contained antibodies that reacted with the pseudoglobulin fraction after all of the antibodies reacting with alpha-globulin had been removed. This observation is evidence that the globulin- $X$ fraction contains more than one antigen. In order to remove all of the antibodies for globulin- $X$ from such antisera, the absorption had to be continued to a point where a large part of the antibody for the alpha-globulin was also removed and the re- sulting sera were too weak to be used for the quantitative determination of alpha-globulin. Therefore, only the first bleedings from the immunized rabbits should be used for the quantitative determination of alpha-globulin.

\section{Standardization of the absorbed antiserum}

One ml. of the antiserum was set up with various amounts of alpha-globulin, Preparation $\mathrm{P}-4$, in a volume of $4 \mathrm{ml}$. The tubes were treated exactly as described in the experiments on serum Number 389. All determinations were made in duplicate, except where noted, and calibrated pipettes were used throughout. The quantity of alpha-globulin nitrogen used, the amount of nitrogen precipitated, and the tests on the supernatants are given in Table III as well as the values calcu-

TABLE III

Nitrogen precipitated from absorbed serum Number 1 by alpha-globulin, $P-4$

\begin{tabular}{|c|c|c|c|c|c|}
\hline \multirow{3}{*}{$\begin{array}{l}\text { Alpha- } \\
\text { globulin } \\
\text { nitrogen }\end{array}$} & \multicolumn{2}{|c|}{$\begin{array}{l}\text { Total nitrogen } \\
\text { precipitated }\end{array}$} & \multicolumn{3}{|c|}{$\begin{array}{l}\text { Tests upon supernatant } \\
\text { fluids }\end{array}$} \\
\hline & \multirow{2}{*}{ Found } & \multirow{2}{*}{$\begin{array}{l}\text { Calcu- } \\
\text { lated* }\end{array}$} & \multicolumn{3}{|c|}{ Added } \\
\hline & & & $\begin{array}{l}\text { Anti- } \\
\text { serum }\end{array}$ & $\begin{array}{l}\text { Alpha- } \\
\text { globulin }\end{array}$ & $\begin{array}{l}\text { Pseudo- } \\
\text { globulin }\end{array}$ \\
\hline $\begin{array}{c}\text { mgm. } \\
0.0174 \\
0.0347 \\
0.0521 \\
0.0694 \\
0.0868 \\
0.1041\end{array}$ & $\begin{array}{l}\text { mgm. } \\
0.147 \\
0.258 \\
0.329 \\
0.391 \\
0.440 \\
0.448 \dagger\end{array}$ & $\begin{array}{c}\text { mgm. } \\
0.147 \\
0.260 \\
0.340 \\
0.387\end{array}$ & $\begin{array}{l}- \\
- \\
+\end{array}$ & \pm & \pm \\
\hline
\end{tabular}

$* N=9.4 x-55 x^{2}$.

$\dagger$ Single determination.

lated upon the assumption that the reaction is that of a single antigen-antibody system. It will be noted from the tests upon the supernatants that in no case was the presence of both antigen and antibody noted in the same supernatant, and that no residual antibody was present that reacted with the globulin- $X$ contained in the pseudoglobulin fraction.

A chart was prepared by plotting the amount of nitrogen precipitated against the quantity of alpha-globulin used and a smooth curve was drawn through the points. It has been shown by previous work (6) that such a curve may be used for the quantitative estimation of an antigen provided certain conditions are controlled. The 
amount of antigen in the sample analyzed must not be excessive. Tests upon the supernatant fluid should always be made and should show the presence of an excess of antibody and the absence of antigen. The analysis should be carried out under exactly the same conditions followed in the standardization of the antiserum: i.e., the volume of the antiserum used, the total volume of the reaction mixture, the volume of saline used for washing the precipitate, the length of time the tubes are kept at $37^{\circ} \mathrm{C}$. and in the ice box, the temperature at which the tubes are centrifuged, should all be kept constant.

\section{Analysis of the globulin fractions for alpha-globulin}

Solutions of the four globulin fractions, the water-soluble and water-insoluble euglobulins and pseudoglobulins, from a number of different preparations were made up to contain approximately $0.05 \mathrm{mgm}$. per $\mathrm{ml}$. of nitrogen. Duplicate $1 \mathrm{ml}$. samples of these solutions were set up with $1 \mathrm{ml}$. of the absorbed antiglobulin serum Number 1 and the amount of nitrogen precipitated was determined, following exactly the procedure used in standardizing the antiserum. The quantity of alpha-globulin equivalent to the nitrogen found was read from the chart.

TABLE IV

Alpha-globulin content of globulin fractions

\begin{tabular}{|c|c|c|c|c|c|}
\hline Preparation & Fraction & $\begin{array}{c}\text { Glob- } \\
\text { ulin } \\
\text { nitro- } \\
\text { gen } \\
\text { added }\end{array}$ & $\begin{array}{l}\text { Nitro- } \\
\text { gen } \\
\text { in } \\
\text { pre- } \\
\text { cipi- } \\
\text { tate }\end{array}$ & $\begin{array}{l}\text { Equiva- } \\
\text { lent } \\
\text { amount } \\
\text { of alpha- } \\
\text { globulin } \\
\text { nitrogen }\end{array}$ & $\begin{array}{l}\text { Per } \\
\text { cent } \\
\text { of } \\
\text { total } \\
\text { glob- } \\
\text { ulin }\end{array}$ \\
\hline $\begin{array}{c}\text { P1 } \\
\text { P2-P3 mixture } \\
\text { P5 } \\
\text { P6 }\end{array}$ & 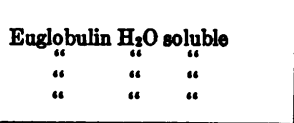 & \begin{tabular}{|l|} 
mom. \\
0.049 \\
0.053 \\
0.053 \\
0.052
\end{tabular} & \begin{tabular}{|l|} 
mom. \\
0.320 \\
0.332 \\
0.332 \\
0.324
\end{tabular} & $\begin{array}{l}\text { mgm. } \\
0.049 \\
0.053 \\
0.053 \\
0.051\end{array}$ & $\begin{array}{r}100 \\
100 \\
100 \\
98\end{array}$ \\
\hline $\begin{array}{l}\text { P1 } \\
\text { P3 } \\
\text { P5 } \\
\text { P6 }\end{array}$ & $\begin{array}{ccc}\text { Euglobulin } \\
\underset{4}{\mathrm{H}_{2} \mathrm{O}} \text { insoluble } \\
\text { “ } & \text { "c } & \text { "c } \\
\text { “ } & \text { " } & \end{array}$ & $\begin{array}{l}0.052 \\
0.047 \\
0.053 \\
0.052\end{array}$ & $\begin{array}{l}0.244 \\
0.226 \\
0.224 \\
0.224\end{array}$ & $\begin{array}{l}0.032 \\
0.029 \\
0.029 \\
0.029\end{array}$ & $\begin{array}{l}62 \\
62 \\
55 \\
56\end{array}$ \\
\hline $\begin{array}{l}\text { P1 } \\
\text { P4 }\end{array}$ & Pseudoglobulin $\mathrm{H}_{6} \mathrm{O}$ soluble & $\begin{array}{l}0.055 \\
0.078 \\
\end{array}$ & $\begin{array}{l}0.146 \\
0.188 \\
\end{array}$ & $\begin{array}{l}0.017 \\
0.023\end{array}$ & $\begin{array}{l}31 \\
29\end{array}$ \\
\hline $\begin{array}{l}\text { P1 } \\
\text { P3 } \\
\text { P6 }\end{array}$ & $\underset{\text { Pseudoglobulin }}{\mathrm{H}_{2} \mathrm{O}}$ insoluble & $\begin{array}{l}0.049 \\
0.124 \\
0.061\end{array}$ & $\begin{array}{l}0.243 \\
0.393 \\
0.224\end{array}$ & $\begin{array}{l}0.032 \\
0.070 \\
0.029\end{array}$ & $\begin{array}{l}65 \\
57 \\
48\end{array}$ \\
\hline
\end{tabular}

The results of the analyses are given in Table IV. This table showed that, within a small experimental error, the amount of nitrogen precipitated from the antiserum by each of the different preparations of the water soluble euglobulin was identical with that precipitated by the same quantity of Preparation $\mathrm{P}-4$ which was used to standardize the antiserum. All of the preparations were exactly the same in their ability to react with alpha-antibody. This uniformity in the preparations tends to eliminate the possibility that the alpha-globulin in this fraction was associated with a second component which did not react with the antiserum. It would not be reasonable to expect preparations made from sera of different individuals to contain a uniform percentage of an inert protein. The results of the analyses therefore indicate that the water-soluble euglobulin fraction is pure alpha-globulin.

As indicated by the experiments with the unabsorbed rabbit antiserum, the other fractions are all mixtures containing both alpha-globulin and globulin- $X$. The water-soluble euglobulin fractions contained between 55 and 62 per cent of alpha-globulin, the water-insoluble pseudoglobulin between 48 and 65 per cent, while the watersoluble pseudoglobulin contained only 30 per cent of this protein. The variation in the alpha-globulin content of the water-insoluble fractions was small whether the material was prepared from the euglobulin or from the pseudoglobulin fraction. The composition was nearly the same whether the material was prepared from a solution rich in alpha-globulin or one rich in globulin-X.

\section{Reaction of alpha-globulin with globulin- $X$}

The constancy of composition of the waterinsoluble globulin suggested that it was a chemical compound of the different globulins. If this is true, mixing solutions of the two water-soluble fractions should result in the formation of a precipitate. A solution of the water-soluble euglobulin fraction of Preparation $\mathrm{P}-4$ containing 0.88 mgm. of alpha-globulin nitrogen was added to a solution of the water-soluble pseudoglobulin fraction containing $0.77 \mathrm{mgm}$. of globulin nitrogen, of which $0.54 \mathrm{mgm}$. was globulin- $X$ nitrogen, at $0^{\circ} \mathrm{C}$. A heavy precipitate formed immediately. After centrifugation in the cold, the supernatant fluid was analyzed and found to contain 0.42 mgm. of nitrogen, leaving $1.23 \mathrm{mgm}$. of nitrogen in the precipitate. If the assumption is made that all of the globulin- $X$ was precipitated, the insoluble protein contained 56 per cent alpha-globulin and 44 per cent globulin- $X$. 
The precipitate, which in the cold formed a semi-opaque gelatinous mass, and upon warming to room temperature liquefied to a very viscous transparent fluid, was readily soluble in 0.9 per cent $\mathrm{NaCl}$ solution. Dilutions of this solution containing $0.0545 \mathrm{mgm}$. of nitrogen precipitated $0.230 \mathrm{mgm}$. of nitrogen from antiserum Number 1 , an amount equivalent to $0.030 \mathrm{mgm}$. of alphaglobulin nitrogen. Thus upon analysis, the precipitate was found to contain 55 per cent of alphaglobulin, confirming the estimate arrived at above. This value is also in agreement with the values found for the water insoluble euglobulin and pseudoglobulin fractions, and supports the hypothesis that the water insoluble globulin is a compound of alpha-globulin and globulin- $X$.

\section{Alpha-globulin content of normal human serum}

Since the absorbed antiserum is specific for alpha-globulin, it can be used for the determination of alpha-globulin in unfractionated human serum. Thirteen samples of serum from adults in normal health were analyzed for total albumin and globulin by the Howe method (1) and for alphaglobulin by the precipitin method. Duplicate determinations of the amount of nitrogen precipitated from $1 \mathrm{ml}$. of absorbed antiserum Number 1 by the addition of $1 \mathrm{ml}$. of a 1:100 dilution of each serum were made following the procedure used for the standardization of the antiserum. The amount of alpha-globulin nitrogen equivalent to the nitrogen in the precipitate was obtained from the standardization chart. The values for alpha-globulin nitrogen were multiplied by the factor 6.25 to obtain values comparable to the albumin and globulin figures from the Howe method. The values for globulin- $X$ were obtained by subtracting the alpha-globulin figures from the total globulin.

The results given in Table $\mathrm{V}$ show that in these thirteen sera the alpha-globulin content varied between 1.1 and 2.1 grams per $100 \mathrm{ml}$. of serum with ten of the values falling between 1.3 and 1.6 grams per $100 \mathrm{ml}$. These values form from 58 to 78 per cent of the total globulin of the sera. The globulin- $X$ content varied between 0.4 and 1.0 with ten of the values lying between 0.6 and 0.8 gram per $100 \mathrm{ml}$. No correlation was found between any of these values and the values for euglobulin, as determined by the Howe method.
TABLE V

Alpha-globulin content of normal human sera

\begin{tabular}{|c|c|c|c|c|c|c|c|c|c|}
\hline Person & Date & Sex & Age & $\underset{\min }{\text { Albu- }}$ & $\begin{array}{l}\text { Glob- } \\
\text { ulin }\end{array}$ & $\begin{array}{l}\text { Eu- } \\
\text { glob- } \\
\text { ulin }\end{array}$ & $\begin{array}{l}\text { Alpha- } \\
\text { glob- } \\
\text { ulin }\end{array}$ & $\begin{array}{l}\text { Glob- } \\
\text { ulin } \\
-X\end{array}$ & $\begin{array}{l}\text { Alphag } \\
\text { dobulin }\end{array}$ \\
\hline & 1887 & & years & $\begin{array}{c}\text { grams } \\
\text { per } \\
100 \\
\text { ml. }\end{array}$ & $\begin{array}{c}\text { grams } \\
\text { per } \\
100 \\
\text { ml. }\end{array}$ & $\begin{array}{c}\text { grams } \\
\text { per } \\
100 \\
\text { ml. }\end{array}$ & $\begin{array}{c}\text { grams } \\
\text { per } \\
100 \\
\text { ml. }\end{array}$ & $\begin{array}{c}\text { grams } \\
\text { per } \\
100 \\
m l .\end{array}$ & $\begin{array}{c}\text { per cent } \\
\text { of } \\
\text { total } \\
\text { globulin }\end{array}$ \\
\hline $\begin{array}{l}\text { Re.... } \\
\text { Ry.... } \\
\text { Se..... } \\
\text { Ma.... } \\
\text { Ke.... } \\
\text { Par.... } \\
\text { Do.... } \\
\text { Fl..... } \\
\text { Ki.... } \\
\text { Da.... } \\
\text { Me.... } \\
\text { Pa.... } \\
\text { St..... }\end{array}$ & \begin{tabular}{|l|} 
May 5 \\
May 5 \\
May 5 \\
May 5 \\
May 5 \\
February 3 \\
June 14 \\
June 14 \\
June 14 \\
June 16 \\
June 16 \\
June 16 \\
June 16
\end{tabular} & $\begin{array}{l}\mathbf{F} \\
\mathbf{F} \\
\mathbf{M} \\
\mathbf{M} \\
\mathbf{M} \\
\mathbf{M} \\
\mathbf{F} \\
\mathbf{M} \\
\mathbf{M} \\
\mathbf{F} \\
\mathbf{M} \\
\mathbf{M} \\
\mathbf{M}\end{array}$ & $\begin{array}{l}43 \\
24 \\
38 \\
31 \\
38 \\
26 \\
24 \\
28 \\
33 \\
28 \\
28 \\
31 \\
27\end{array}$ & $\begin{array}{l}4.3 \\
5.4 \\
5.4 \\
5.5 \\
4.4 \\
4.9 \\
5.0 \\
5.0 \\
4.8 \\
5.1 \\
4.9 \\
5.2 \\
5.0\end{array}$ & $\begin{array}{l}2.2 \\
1.8 \\
2.4 \\
1.6 \\
2.1 \\
2.3 \\
2.0 \\
2.4 \\
2.7 \\
2.2 \\
2.3 \\
2.2 \\
2.6\end{array}$ & $\begin{array}{l}0.4 \\
0.4 \\
0.6 \\
0.5 \\
0.4 \\
0.5 \\
0.3 \\
0.3 \\
0.4 \\
0.3 \\
0.4 \\
0.5 \\
0.7\end{array}$ & $\begin{array}{l}1.5 \\
1.4 \\
1.6 \\
1.1 \\
1.3 \\
1.4 \\
1.3 \\
1.4 \\
2.1 \\
1.4 \\
1.6 \\
1.4 \\
1.9\end{array}$ & $\begin{array}{l}0.7 \\
0.4 \\
0.8 \\
0.5 \\
0.8 \\
0.7 \\
0.7 \\
1.0 \\
0.6 \\
0.8 \\
0.7 \\
0.8 \\
0.7\end{array}$ & $\begin{array}{l}68 \\
78 \\
67 \\
69 \\
62 \\
61 \\
65 \\
\mathbf{5 8} \\
78 \\
64 \\
70 \\
64 \\
73\end{array}$ \\
\hline
\end{tabular}

Alpha-globulin in the serum of patients with alcoholic cirrhosis of the liver and chronic glomerulonephritis

Two diseases, alcoholic cirrhosis of the liver and chronic glomerulonephritis, were chosen for study because they produce definite changes in the level of serum protein and are marked by certain abnormalities in water metabolism.

The results of the analyses of sera from 13 patients suffering from various stages of alcoholic cirrhosis of the liver are given in Table VI. The ten cases marked with Roman numerals are described by Patek in another paper (9). It will be seen that the high globulin values observed in this disease are due to an increase in the alpha-globulin, the globulin- $X$ values remaining within the limits found for normal sera. In all of the cases showing extensive liver damage, the alpha-globulin formed more than 80 per cent of the total globulin. The cases that showed marked clinical improvement, upon following the treatment described by Patek, showed a decrease in the percentage of alpha-globulin.

Table VI also shows the values obtained on seven cases of chronic glomerulonephritis. All of the patients studied in this group were in the nephrotic stage of the disease, showing extensive edema and marked albuminuria. The sixth case, Jo., may have been a case of pure nephrosis. The results show that in six of the cases, although the total globulin was within the normal limits, the alpha-globulin was decreased, forming only between 26 and 47 per cent of the total, while the globulin- $X$ fraction was increased so that it 
TABLE VI

Alpha-globulin content of sera from patients with cirrhosis or nephritis

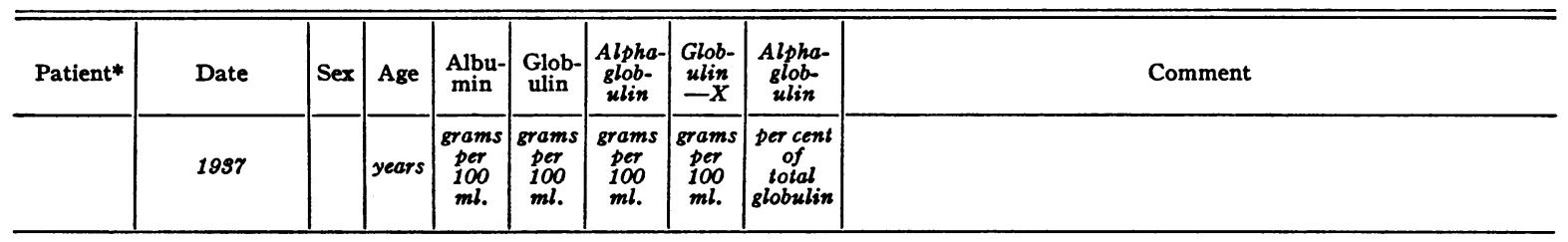

ALCOHOLIC CIRRHOSIS OF THE LIVER

\begin{tabular}{|c|c|c|c|c|c|c|c|c|c|}
\hline & pril 27 & F & 45 & 3.5 & 3.0 & 2.4 & 0.6 & 80 & $\begin{array}{l}\text { General improvement. No ascites for } 5 \mathrm{n} \\
\text { lowing } 7 \text { months' history of ascites. }\end{array}$ \\
\hline & Jur & & & 3.7 & 3.0 & 2. & 0. & 73 & Continued improvement. \\
\hline Ca. II & & $\mathbf{M}$ & 63 & 3.9 & 3.9 & 2 . & 1. & & $\begin{array}{l}\text { General improvement. No ascites for } 7 \text { months fol- } \\
\text { lowing } 7 \text { months' history of ascites. }\end{array}$ \\
\hline Po. III & April 14 & $F$ & 49 & 3.3 & 2.0 & 1.6 & 0.4 & 80 & $\begin{array}{l}\text { Jaundiced; no ascites. Considered case of alcoholic } \\
\text { hepatitis. }\end{array}$ \\
\hline Har. IV & May 24 & $\mathbf{M}$ & 40 & 3.7 & 3.3 & 2.1 & 1.2 & 64 & Jaundiced; no ascites. Considered case of alcoholic \\
\hline Bo. VI & $\mid \begin{array}{l}\text { January } 22 \\
\text { February } 15\end{array}$ & $\mathbf{M}$ & 64 & $\begin{array}{l}2.9 \\
2.6\end{array}$ & $\begin{array}{l}4.6 \\
5.3\end{array}$ & $\begin{array}{l}4.1 \\
4.1\end{array}$ & $\begin{array}{l}0.5 \\
1.2\end{array}$ & $\begin{array}{l}89 \\
78\end{array}$ & $\begin{array}{l}\text { Ascites of one month duration. } \\
\text { Ascites present. Bronchopneumonia, causative organ- } \\
\text { ism unknown. }\end{array}$ \\
\hline $\begin{array}{l}\text { Br. VII } \\
\text { Ar. VIII }\end{array}$ & Jun & $\mathbf{F}$ & $\begin{array}{l}48 \\
45\end{array}$ & $\begin{array}{l}2.9 \\
4.3\end{array}$ & $\begin{array}{l}2.9 \\
2.3\end{array}$ & $\begin{array}{l}2.5 \\
1.7\end{array}$ & $\begin{array}{l}0.4 \\
0.6\end{array}$ & $\begin{array}{l}86 \\
74\end{array}$ & $\begin{array}{l}\text { Ascites present. Profound anemia of primary type? } \\
\text { No ascites for } 1 \text { month following ascites of unknown } \\
\text { duration. Anemia. }\end{array}$ \\
\hline Tu. IX & & $\mathbf{N}$ & 52 & $\begin{array}{l}4.1 \\
4.3\end{array}$ & $\begin{array}{l}4.4 \\
4.3\end{array}$ & $\begin{array}{l}3.7 \\
3.4\end{array}$ & 0. & 79 & $\begin{array}{l}\text { Ascites for } 8 \text { months. Diuresis May 10, } 1937 . \\
\text { No ascites for } 1 \text { month. }\end{array}$ \\
\hline & A & $\mathbf{M}$ & 49 & 3. & 3. & 3.1 & 0 & 82 & $\begin{array}{l}\text { No history of ascites. Mild cirrhosis with chronic } \\
\text { glomerulonephritis. }\end{array}$ \\
\hline & Jur & $F$ & & 4.0 & 3. & 2. & 0. & 77 & \\
\hline Ha. $\mathrm{XI}_{0}$ & & $F$ & 55 & $\begin{array}{l}2.1 \\
2.9\end{array}$ & 3.4 & 2.8 & 0. & $\begin{array}{l}82 \\
82\end{array}$ & $\begin{array}{l}\text { Ascites of } 5 \text { months' duration. } \\
\text { Ascites of } 6 \frac{1}{2} \text { months' duration. Died June } 14,1937 .\end{array}$ \\
\hline Has. & May & $\mathbf{M}$ & 66 & 3.8 & 3.4 & 3.1 & 0. & 91 & $\begin{array}{l}\text { Very slight cirrhosis on admission. No ascites. } \\
\text { Chronic glomerulonephritis? }\end{array}$ \\
\hline $\begin{array}{l}\text { “” } \\
\text { Ho. } \\
\text { La. }\end{array}$ & $\begin{array}{l}\text { June } 16 \\
\text { June } 5 \\
\text { June } 5\end{array}$ & $\mathbf{M}$ & $\begin{array}{l}67 \\
38\end{array}$ & $\begin{array}{l}3.7 \\
1.5 \\
2.8\end{array}$ & $\begin{array}{l}3.0 \\
4.7 \\
2.0\end{array}$ & $\begin{array}{l}2.3 \\
3.9 \\
2.0\end{array}$ & $\begin{array}{l}0.7 \\
0.8 \\
0.0\end{array}$ & $\begin{array}{r}77 \\
83 \\
100\end{array}$ & $\begin{array}{l}\text { Evidence for cirrhosis lacking at this date. } \\
\text { Ascites } 5 \text { months. Died June } 29,1937 \text {. } \\
\text { Ascites } 3 \text { months. Anemia. Died June 28, } 1937 . \\
\text { Tubercular meningitis. }\end{array}$ \\
\hline
\end{tabular}

CHRONIC GLOMERULAR NEPHRITIS

\begin{tabular}{l|l|l|l|l|l|l|l|l|ll}
\hline Mu. & April 22 & M & 40 & 1.9 & 2.1 & 0.9 & 1.2 & 43 & Generalized edema. & \\
Ga. & April 22 & M & 21 & 2.2 & 2.4 & 0.9 & 1.5 & 38 & Generalized edema. \\
Wh. & April 14 & F & 20 & 2.8 & 1.9 & 0.9 & 1.0 & 47 & Generalized edema. \\
Ka. & April 14 & F & 14 & 3.0 & 1.6 & 0.6 & 1.0 & 38 & Generalized edema. & \\
Hi. & April 12 & M & 54 & 2.1 & 2.8 & 1.0 & 1.8 & 36 & Nephrotic stage. & Died June 5, 1937. Pneumo- \\
Jo. & May 3 & M & 15 & 1.6 & 1.9 & 0.5 & 1.2 & 26 & Possible nephrosis. Died \\
Rh. & April 22 & F & 46 & 1.5 & 3.4 & 3.0 & 0.4 & 88 & Geccus peritonitis. & Gied May 3, 1937. \\
\hline
\end{tabular}

* The cases marked with Roman numerals are described by Patek in another paper (9).

formed from 50 to 75 per cent of the total globulin, instead of from 22 to 42 per cent, as found in normal individuals.

The variations in the alpha-globulin content of the serum at various stages of these and other diseases are being studied and will be reported in a later paper.

\section{SUM MARY}

The work reported in this paper confirms the observation of earlier workers that the globulin fraction of human serum contains at least two proteins that are antigenically different. When rabbits were immunized with the whole globulin or with one of the water-insoluble fractions of the globulin, the resulting antiserum contained precipitating antibodies for at least two different proteins. Quantitative experiments show that most of the antibody in the antisera tested is specific for one of the globulins, antibodies for the other globulin or globulins representing only about 10 per cent of the total amount. It was found pos- 
sible to absorb out these antibodies by treating the antiserum with small amounts of a fraction rich in the corresponding globulin and in this way obtain an antiserum that reacted with only one kind of globulin.

This absorbed antiserum was used as a reagent for the quantitative determination of the amount of corresponding protein contained in human serum and in fractions of the serum globulin obtained by precipitation with ammonium sulfate and by dialysis. The information thus obtained led to the isolation of a fraction of the serum globulin that behaved like a pure protein in its reactions with antiserum. This protein, which has been called alpha-globulin, was water-soluble and formed from 58 to 78 per cent of the total globulin present in normal human serum. The remainder of the globulin has not been isolated in pure form; the best preparations thus far obtained still contain 30 per cent of alpha-globulin. Although evidence has been presented that the remainder of the globulin is itself a mixture of antigens, it has been found convenient to call it globulin- $X .^{3}$ The purest preparations of globulin- $X$ were also water-soluble. When solutions of alpha-globulin and globulin- $X$ were mixed in the absence of salt, a precipitate was formed which contained 55 per cent of alpha-globulin. The composition of this precipitate was very close to that of the waterinsoluble globulin obtained when either the euglobulin fraction or the pseudoglobulin fraction is dialyzed free from salts. The constant composition of this protein suggested that it was a compound of the two water-soluble globulins.

\section{CONCLUSIONS}

1. A fraction of the globulin of normal human serum has been isolated which behaves like a pure protein in its reactions with antiglobulin rabbit serum. This protein has been called alpha-globulin.

2. Evidence has been presented that the remainder of the globulin, called for convenience

\footnotetext{
8 These names, alpha-globulin and globulin-X, are preferred by the author to the terms Globulin I and Globulin II suggested by Harris and Eagle (5) since they avoid the possibility of being confused with the terms Pseudoglobulin I and Pseudoglobulin II which refer to certain fractions obtained by precipitation with sodium sulfate.
}

globulin- $X$, is a mixture containing more than one antigen.

3. Both alpha-globulin and globulin- $X$ are water soluble. The familiar globulin, insoluble in water but soluble in dilute salt solutions, is formed when these two water soluble fractions are mixed.

4. The water insoluble serum globulin is a compound of alpha-globulin and globulin- $X$ containing approximately 55 per cent of alpha-globulin.

5. Normal human serum contains between 1.1 and 2.1 grams of alpha-globulin and between 0.4 and 1.0 gram of globulin- $X$ per $100 \mathrm{ml}$.

6. In a limited series of patients with cirrhosis of the liver or chronic glomerulonephritis with edema, the quantities and proportions of these two proteins are markedly changed from the normal values.

\section{BIBLIOGRAPHY}

1. Howe, P. E., The function of the plasma proteins. Physiol. Rev., 1925, 5, 439.

2. Lustig, B., Zur Kenntnis der Unterfraktionen der Globuline und Albumine im Serum. Biochem. Ztschr., 1930, 225, 247.

3. Chick, H., The viscosity of protein solutions. II. Pseudoglobulin and euglobulin (horse). Biochem. J., 1914, 8, 261.

Sorensen, S. P. L., The solubility of proteins. Harvey Lect., 1924-5, 20, 25.

Block, R. J., The basic amino acids of serum proteins. J. Biol. Chem., 1933, 103, 261.

4. Gay, F. P., and Adler, A. M., On the chemical separation of the sensitizing fraction (anaphylactin) from horse serum. J. Med. Research, 1908, 18, 433.

Dale, H. H., and Hartley, P., Anaphylaxis to the separated proteins of horse serum. Biochem. J., 1916, 10, 408.

Kato, Y., Anaphylaxis induced by serum albumin. Mitt. a. d. med. Fakult. d. k. Univ. zu Tokyo, 1917, 18, 195.

Doerr, R., and Berger, W., Immunologische Analyse der komplexen Struktur der Serumeiweisses. Ztschr. f. Hyg. u. Infectionskr., 1922, 96, 191.

Stern, E., Serumglobulin und Serumalbumin als Anaphylaktogene. Arch. f. Hyg., 1922, 91, 165.

Ruppel, W. G., Ornstein, O., Carl, J., and Lasch, G., Lyophile und Lyophobe eiweisskörper als Antigen und Antikörper. Ztschr. f. Hyg. u. Infectionkr., 1922, 97, 188.

Kimura, R., Chemische und serologische Untersuchungen über Blutbestandteile. Ztschr. f. Immunitätsforsch. u. exper. Therap., 1928, 56, 330.

Otto, R., and Iwanoff, K., Ueber die Fraktions- und Artspezifität der Serumfraktionen bei electroosmotisch gespaltenen Seren. Ztschr. f. Immunitätsforsch. u. exper. Therap., 1928, 57, 19. 
5. Hunter, A., On the chemical specificity of precipitins. J. Physiol., 1905, 32, 327.

Harris, T., and Eagle, H., The immunological specificity of the euglobulin and pseudoglobulin fractions of horse and human serum. J. Gen. Physiol., 1935-6, 19, 383.

6. Goettsch, E., and Kendall, F. E., Analysis of albumin and globulin in biological fluids by the quantitative precipitin method. J. Biol. Chem., 1935, 109, 221.

Heidelberger, M., and Kendall, F. E., A quantitative theory of the precipitin reaction. II. The reaction between crystalline egg albumin and its homolo- gous antibody. J. Exper. Med., 1935, 62, 697.

7. Heidelberger, M., and Kendall, F. E., Quantitative studies on the precipitin reaction. The determination of small quantities of a specific polysaccharide. J. Exper. Med., 1932, 55, 555.

8. Glenny, A. T., Pope, C. G., Waddington, H., and Wallace, U., Immunological notes. XXIII. The antigenic value of toxoid precipitated by potassium alum. J. Path. and Bact., 1926, 29, 38.

9. Patek, A. J., Jr., The effect of high vitamin therapy upon the clinical course of patients with alcoholic cirrhosis of the liver (In press). 